\title{
İnşaat sektöründe faaliyet gösteren yüklenicilerin sosyo-kültürel yapısı: Balıkesir ili örneği
}

\author{
Fehmi Çivíici ${ }^{1, *}$, Tülay Çivíici ${ }^{2}$ \\ ${ }^{1}$ Balıkesir Üniversitesi Mühendislik Fakültesi, İnşaat Mühendisliği Bölümü, Çağış kampüsü, Balıkesir \\ ${ }^{2}$ Balıkesir Üniversitesi Mimarlık Fakültesi, Mimarlık Bölümü, Çağış kampüsü, Balıkesir
}

Geliş Tarihi (Received Date): 26.03 .2019

Kabul Tarihi (Accepted Date): 08.07.2019

\section{$\ddot{O} z$}

Yüklenici firmalar, İnşaat Sektörünün ana aktörlerinden biridir. Yüklenici firmaların sosyo-kültürel durumlarını mesleki alanda etkin bir şekilde kullanımı önemlidir. Bu çalışmada yüklenici firma yöneticilerinin sosyo-kültürel yapılarına etki eden faktörlerin belirlenmesi amaçlanmıştır. Bu amaç için, Balıkesir İli genelinde faaliyette olan yükleniciler ile anket ve mülakat çalışması yapılarak elde edilen sosyo-kültürel bilgilerin sektördeki yansımaları konusunda önemli sonuçlara ulaşılmıştır. Bu çalışmada inşaat sektörünün küresel görünümüne önce değinilmiş, sonra faaliyet gösteren yüklenicilerin sosyo-kültürel durumunu etkileyen etmenler detayl bir şekilde sektörel alan çalışmaları ile ortaya çıkarılmıştır. Edinilen etmenlerin mesleğe katkısı ve sektördeki faaliyetlerini nasıl etkilediği tartışılmış, sektördeki verimlerinin artması için sosyo-kültürel yap ile ilgili öneriler vurgulanmıştır.

Anahtar kelimeler: İnşaat sektörü, yüklenici, sosyo-kültürel yapı.

\section{Socio-cultural structure of contractor firms operating in construction: a sample of Balıkesir}

\begin{abstract}
Contractor companies are one of the main actors in the construction sector. It is important to use the socio-cultural status of the contractor companies effectively in the professional field. In this study, it is aimed to determine the factors affecting the sociocultural structures of contractor company managers. For this purpose, significant results have been reached on the reflections of the socio-cultural information obtained

\footnotetext{
*Fehmi ÇIVICİ, fcivici@ balikesir.edu.tr, http://orcid.org/0000-0001-9957-1628

Tülay ÇiViCI, tulay @ balikesir.edu.tr, http://orcid.org/0000-0002-5764-7951

Çalışmada kullanılan verilerin toplanmasında yardım sağlayan öğrencilerimize teşekkür ederiz.
} 
by conducting surveys and interviews with the contractors working in the province of Ballkesir. In this study, the global view of the construction sector was mentioned firstly, and then the factors affecting the socio-cultural status of the active contractors were revealed with sectoral field studies in detail. The contribution of the factors to the profession and how they affect their activities in the sector were discussed and suggestions for socio-cultural structure were emphasized in order to increase their efficiency in the sector.

Keywords: Construction industry, the contractor, socio-cultural structure.

\section{Giriş}

2000' li yıllar ile birlikte ivme kazanan inşaat sektörü Türkiye ekonomisinde belirleyici ve destekleyici konumda olmuştur. Bu sektöre bağlı iş kollarının üretim kapasiteleri ve istihdam oranlarının artması ile yeni paydaşlar türeyerek söz sahibi olmuşlardır. $\mathrm{Bu}$ paydaşların çoğu herhangi bir mesleki eğitim görmeden maddi kaynağı olanların sektöre katılmasından öte bir şey değildir. Bu durum sektördeki üretim sürecinden başlayıp, pazarlama aşamasına kadar birçok sorunu da beraberinde getirmiştir. İnşaat sektörünün uluslararası arenada rekabet üstünlüğü kazanması, inşaat firmalarının yönetim kademelerini oluşturacak mezunlardan hem derinlik hem de genişlik arz edecek özellik ve yetenekler beklemesine neden olmaktadır [1]. Türkiye'deki inşaat firmalarının çoğunluğu profesyonel olmayan en büyük sermaye ortağının söz sahibi olmasıyla kurulmuştur. [2]. Bu oluşumun sektörün doğasında bulunan kendine has özelliklerine uyum sağlayamaması bir çok sorunu gündeme getirmiştir [2]. İnşaat sektöründe temel bileşen olan insan kaynağı proje başarısını etkilemektedir. İnşaat sektörünün birçok meslek grubundaki firmalarla birlikte çalışmasını gerektiren yapısı sebebiyle projelerin düzenli ilerleyebilmesi için etkin ve tutarlı bir iletişim esastır [2]. Sektörde yüklenicilerin sosyo-kültürel yapılarının güçlü oluşu iletişimin doğru ve etkili olmasını sağlayacaktır.

Kültür kelimesi farklı şekillerde tanımlanmıştır. İlk olarak 18. Yüzyılda Avrupa'da barbar kelimesinin karşıtı olan eğitimli insan tanımı olarak yapılmıştır. 1843'de Gustav Klemn, 'İnsanlığın Genel Kültür Tarihi' adlı eserinde bir insan topluluğunun yetenek ve becerileri sanatları ve gelenekleri olarak top yekün yaşama stili şeklinde kültürü tanımlamıştır [3].

İnşaat sektöründe üretim süreci, bir yapının gerçekleştirilmesinin yanı sıra, birbiriyle ilişkili ve birbirine bağlı birçok faaliyetin yerine getirilmesiyle sağlanır [4]. Bu süreçte yüklenici firmaların sosyo kültürel yapısı, teknik donanımlarının yanı sıra, sektördeki tüm paydaşları etkilemesi nedeniyle önemlidir. Yüklenici ve alt yükleniciler birçok aşamada üretime katılarak sorunlar ile yüzü yüze gelmektedir. Domino taşları örneğindeki gibi, sektörün tüm paydaşları etkilenmektedir.

Türk inşaat sektöründe yaşanan problemlerin; bürokratik işlemler, kontrol mekanizmaları ve yönetim yaklaşımlarındaki yetersizliklerden kaynaklandığı düşünülse de, aslında tüm sorunların derinliğinde kültürel çeşitliliğe sahip insan kaynakları yer almaktadir [4]. 
Karyelioğlu [5] çalışmasında; son yıllarda önemli gelişme gösteren inşaat sektörünün ana aktörleri olan yüklenicilerin sosyo-kültürel düzeylerine yönelik bir araştırma yapmıştır. Müteahhitliğin meslek olarak seçilmesindeki nedenlerinin toplumsal arka planı incelenmiştir.

Tekeli ve İlkin [6] yaptıkları çalışmada, küçük inşaat girişimcisi veya taşeron ile büyük inşaat yüklenicisini ayıran en önemli özelliğin iş hacmi ve parasal büyüklük yerine karşılıklı iletişim olduğunu belirtmişlerdir. $\mathrm{Bu}$ anlamda; karşılıklı iletişimin kişilerin sosyo-kültürel yapılarını desteklediğini söylemek doğru olacaktır.

Günümüze kadar lokomotif vazifesi gören sektörün ana aktörlerinden biri olan yüklenicilerin bu çalışma ile Balıkesir ili genelinde sahip oldukları sosyo-kültürel yapılarının araştırılması ve bu yapının mesleki anlamda sektörü nasıl etkilediğinin belirlenmesi yapılmıştır. Çalışmanın ilk bölümünde Ülkemizde sektörün durumuna değinilerek yüklenici firma ve şahısların rolü anlatılmıştır. İkinci bölümde ise; İlimizin sosyo-kültürel yapısına yüklenicilerin katkılarını açıklayabilmek için birebir anket ve mülakat çalışmaları yapılarak önemli sonuçlara ulaşılmıştır. $\mathrm{Bu}$ sonuçlar 1şığında yüklenicilerin sektördeki verimliliğini arttırabilmek adına öneriler sunulmuştur.

\section{2. İnşaat sektörünün güncel durumu}

İnşaat sektörü; ilk önce bina yapım işinin akla gelmesiyle birlikte, enerji santralleri, köprüler, viyadükler, otoyollar, barajlar, havaalanları, limanlar gibi geniş bir faaliyet alanıdır. Günümüzde artan inşaat maliyetlerinin tüketiciye yansıması ile sektörde bir durgunluk dönemi yaşanmasına rağmen halen ayakta kalma başarısını göstererek ülke ekonomisine doğrudan ve dolaylı katkı sunmaktadır. Bu anlamda bir yapının proje aşamasından başlayıp üretimi tamamlanıncaya kadar Mimar, Mühendis ve üretimin çeşitli aşamalarında birçok teknik eleman, işçinin görev aldığı bir istihdam alanıdır. 2017 yılı itibari ile ülke ekonomisinin büyüme indeksi, ekonomik politikalar ve yatırımcıların tercihiyle sektör olumlu yönde gelişmiştir. Araştırmalar 2018 yılı sektöre ait tahminlerde Avrupa'da bir durgunluk, $A B D$ ve Kanada'da büyüme öngörmektedir. Rusya da ise beklenen büyüme; bu ülkede faaliyet gösteren müteahhitlik firmaları içinde önemli bir durumdur [7].

Ülkemiz de ise sektörü konut ve altyapı projelerinin yoğunluğu sebebiyle önemli bir ivme kazanmıştır. 2018 yılı tahminleri sektördeki pazarın Ortadoğu ve Afrika ülkelerine kayabileceğini söylemektedir. $\mathrm{Bu}$ beklenti Türk yüklenicileri içinde bir fırsat niteliğindedir. 2016-2017 yıllarındaki sektörün olumlu durumu, 2018'e bakıldığında sektör paydaşlarının daha konservatif olduğu görülmektedir [8]. Üretilen konut miktarının tüketilememesi yani; arz-talep dengesizliğinin içinde bulunduğumuz yılda devam etmesi sektörün aktörleri olan yükleniciler açısından olumsuz sonuçlar doğurabilecektir. Ülkemiz içinde faaliyet gösteren sektörün önemli temsilcileri 1972 den beri yurt dişında hizmet vermektedir. Uluslararası inşaat sektörü dergisi Engineering News-Record (ENR)' nin 2018 yılı açıklanan dünyanın en büyük 250 uluslararası yüklenicileri listesinde Türkiye'den 45 firma vardır [9]. ENR' a göre; uluslararası sektörde iş hacmi \%14 küçülürken Türk firmaları bu durumdan etkilenmeden iş hacmi ve pazar paylarını arttırmışlardır [9]. İnşaat sektörü 2017 yılında cari fiyatlarla 265 milyar 680 milyon TL katma değer yaratmıştır. Bu veriler ile sektörün Gayri Safi Yurtiçi Hasıladan aldığı pay \% 8,6 olmuştur [7]. 


\section{3. İnşaat sektöründe yüklenicilerin rolü}

Ülkemiz ve dünyada ekonomiye ivme kazandıran sektör farklı yüklenicileri bir arada bulundurmaktadır. İnşaat faaliyetleri; son yıllarda oluşan ihtiyaçlar ve zorunluluklar çerçevesinde akıllı bina, ofis, eğlence-aktivite merkezleri ve altyapı odaklı olmuştur. Ayrıca faaliyetlerin arasına yasalarla desteklenen kentsel dönüşüm olgusunu da katmak gerekir. İşte yükleniciler bu projelerin tasarımı ve hayata geçirilmesi aşamalarında görev alarak kendi sermaye, bilgi ve beceri, teknik altyapıları oranında ürünlerin ortaya çıkarılmasında hizmet vermektedirler. Yüklenicilerin sektördeki iş hacminin genelde konut türü yapılar olduğunu görülmektedir [8].

Ülkemizde yüklenici olarak çalışabilmek yeterli birikimi olan her kişi açısından mümkündür. Sadece müteahhitlik yetki belgesinin Çevre ve Şehircilik Bakanlığı'na başvurularak alınması yeterlidir. $\mathrm{Bu}$ denli denetimsiz bir işleyiş problemli sonuçlar doğurabilmektedir.

\section{Balıkesir’in sosyo-kültürel yapısı}

Balıkesir ve çevresinin yerleşim yeri olarak kullanılması M.Ö. 3200' li yıllara kadar uzanmaktadır. İl, Frig, Lidya, Pers, Makedonya, Bergama Krallı̆̆ı, Roma ve Bizans dönemlerini yaşayarak zengin bir tarihsel dokuya sahiptir [10]. 1071 Malazgirt Savaşı'ndan sonra Karesi Beyliğine merkez olmuştur. 1923 yılında Karesi Vilayeti olan ilimiz 1926 yılında ismi değiştirilerek Balıkesir olmuştur [10]. Tarihsel kültürel bir merkez olan Balıkesir, coğrafi konumu, doğal zenginlikleri ile yaşam şartları açısından tercih edilebilir bir şehirdir. Coğrafi konumuna bağlı olarak geçim kaynakları şekillenmiştir. Denize kıyısı olan ilçelerinde balıkçılık, zeytincilik, bağcılık, iç kısımlarda ise ormancılık, hayvancılık ve tarım alanlarında faaliyetler gösterilmektedir. Sanayi ve ticaret alanında ise tarıma dayalı endüstri kolları gelişmiştir. Sanayi alanına destek veren yeraltı zenginliklerini de unutmamak gerekir. Dünyanın en büyük bor tuzu rezervi il sınırları içindedir. Nüfus yapısına bakıldığında eğitimli bireylerin oranının yüksek olduğunu görürüz. Sosyo-kültürel yapı olarak zengin bir potansiyele sahip olması ilin yükleniciler açısından da tercih sebebidir. Bu çalışma ile; ilde faaliyette olan yüklenicilerin sosyo-kültürel yapılarının mesleklerini icra ederken kente katkısının nasıl olduğu araştırılmaktadır.

\section{Araştırma yöntemi}

İnşaat sektöründe faaliyet gösteren yüklenicilerin sosyo-kültürel yapılarının incelenmesini amaçlayan bu çalışmada veri toplama aracı olarak anket formu hazırlanmıştır. Anket çalışması için Karyelioğlu [5]'nun çalışmasından yararlanılmış ve gerekli izinler alınmıştır. Anket formunun ilk bölümü katılımcıların demografik özelliklerini (yaşları, doğum yerleri, kardeş sayıları, eğitim durumları) içeren sorulardan oluşmaktadır. Sonraki bölüm ise, katılımcının baba/aile mesleğini sürdürüp sürdürmediğini ölçmeye yönelik soruları içermektedir. Son bölümde ise katılımcının mesleki gelişime katkı sağlayacak etkinlik (seminer, mesleki kuruluşlara üyelik, vb.) ve yayın takip (süreli yayın, mesleki gelişime yönelik dergiler, vb.) düzeyleri ve mesleki doyum düzeylerini belirlemeye yönelik sorular bulunmaktadır. Araştırmada katılımcının bireysel özelliklerini içeren sorular açık uçlu sorulardan, diğer bölümdeki sorularsa evet (=1) / hayır (=2) olmak üzere iki seçenekli yanıtları içermektedir. 
Anket formu hazırlandıktan sonra katılımcılara ulaşabilmek için; Balıkesir Ticaret Odası verilerinden [11] il genelinde konut, inşaat alanında faaliyet gösteren 572 üye tespit edilmiştir. $\mathrm{Bu}$ üyelerden il merkezinde faaliyet gösteren 60 yüklenici firmadan 40'ına erişim sağlanmıştır. Örneklem grubunun \% 66' sinı temsil eden katılımcılar ile yüz yüze görüşülerek anket uygulanmıştır.

Katılımcılardan elde edilen verilerin analizleri için SPSS 22, Microsoft Office Excel 2010 yazılımlarından yararlanılmıştır. Analizlerde ikiden fazla değişken (yaş, eğitim, baba mesleği) ile bağımlı değişkenler arasındaki ilişkinin incelenmesinde ANOVA (tek yönlü varyans) analizi kullanılmıştır.

\subsection{Bulgular}

\subsubsection{Katılımcıların demografik özellikleri}

Elde edilen bulgular katılımcıların yaş aralıklarının \%40' nın 41-50 yaş aralığında, \% 32 'sinin 31-40 aralığında, \%20' sinin 20-30 aralığında, \%8' nin ise 51-60 aralığında değiştiğini göstermektedir (şekil 1). En düşük oranın 51-60 yaş aralığındayken en yüksek oran ise; 41-50 yaş grupları arasındadır.

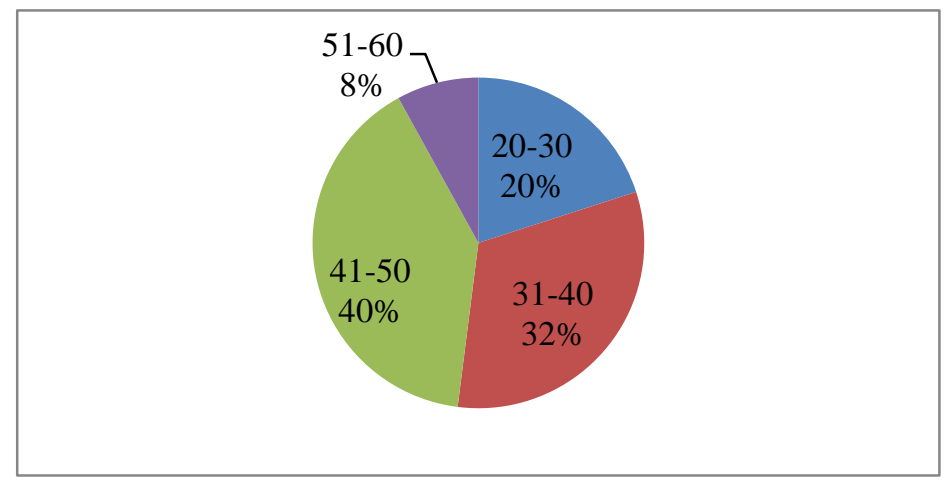

Şekil 1. Katılımcıların yaş aralıkları.

Katılımcıların kardeş sayısı incelendiğinde 1 ile 8 kardeş sayısı arasında değişim göstermektedir. Katılımcılar yüksek oranda 8 kardeş (\%22), 7 kardeş (\%19), 6 kardeş $(\% 17)$ ve 5 kardeş (\%14) sayılarına sahiptir. En düşük oran 1 kardeş (\%3) sayısına sahip katılımcılardır (şekil 2).

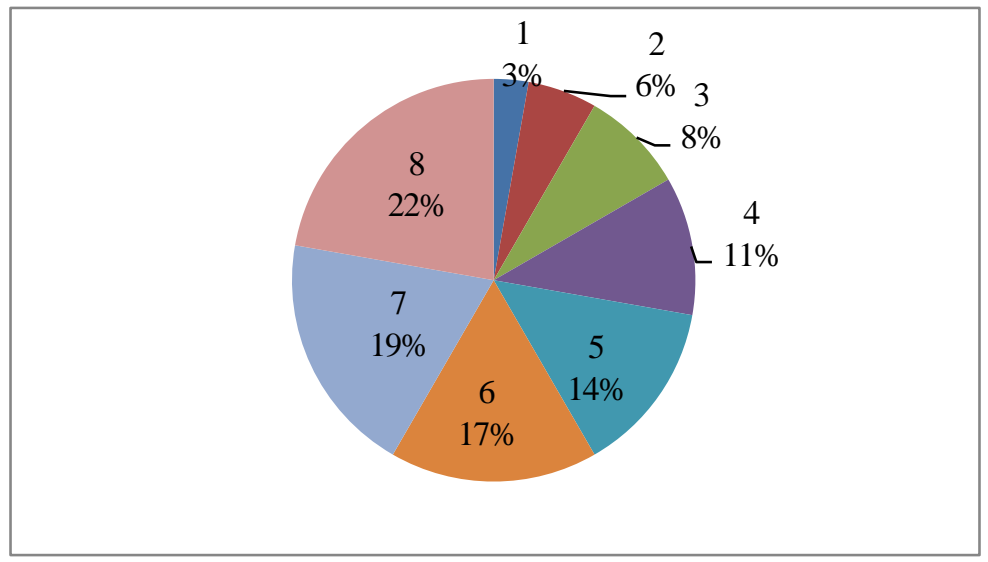

Şekil 2. Katılımcıların kardeş sayıları. 
Çalışmada elde edilen bir başka bulgu katılımcıların yüksek oranda (\% 60; 24 katılımcı) Balıkesir doğumlu olduğudur. Balıkesir ili dışında Ankara (\%2), Mersin (\%3), Manisa (\%3), Malatya (\%5), Kayseri (\%3), İzmir (\%5), İstanbul (\%8), Eskişehir (\%2), Edirne (\%2), Çanakkale (\%2), Bursa (\%5) illeri arasında dağılım göstermektedir (şekil 3).

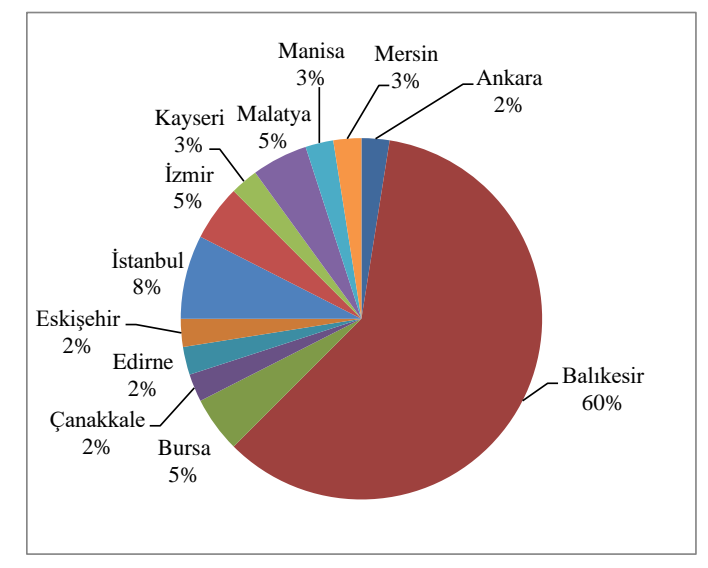

Şekil 3. Katılımcıların doğum yerleri.

Katılımcıların eğitim düzeylerine ilişkin bulgular \% 55' inin lisans, \% 40' nın orta öğretim, \% 5'inin ise yüksek lisans düzeyinde eğitim düzeyine sahip olduğunu göstermektedir (şekil 4).

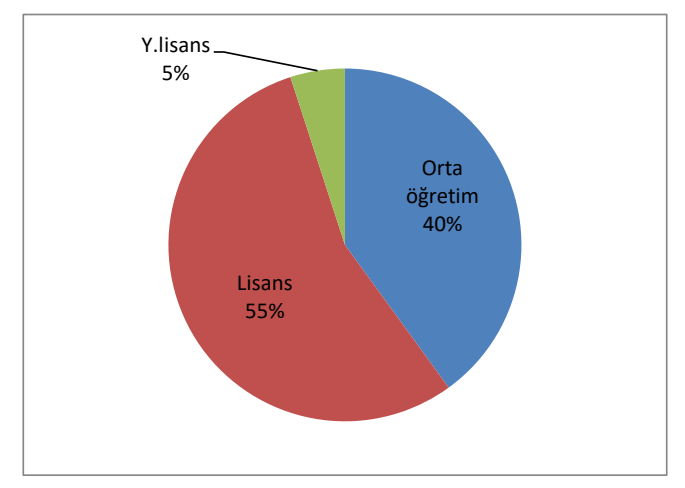

Şekil 4. Katılımcıların eğitim düzeyleri.

Katılımcıların baba mesleği bulguları; \%10' unun emekli, \%3' ünün memur, \%87' sinin ise serbest meslek (marangoz, tesisatçı, emlakçı vb.) sahibi olduğu görülmektedir (Şekil $5)$. 


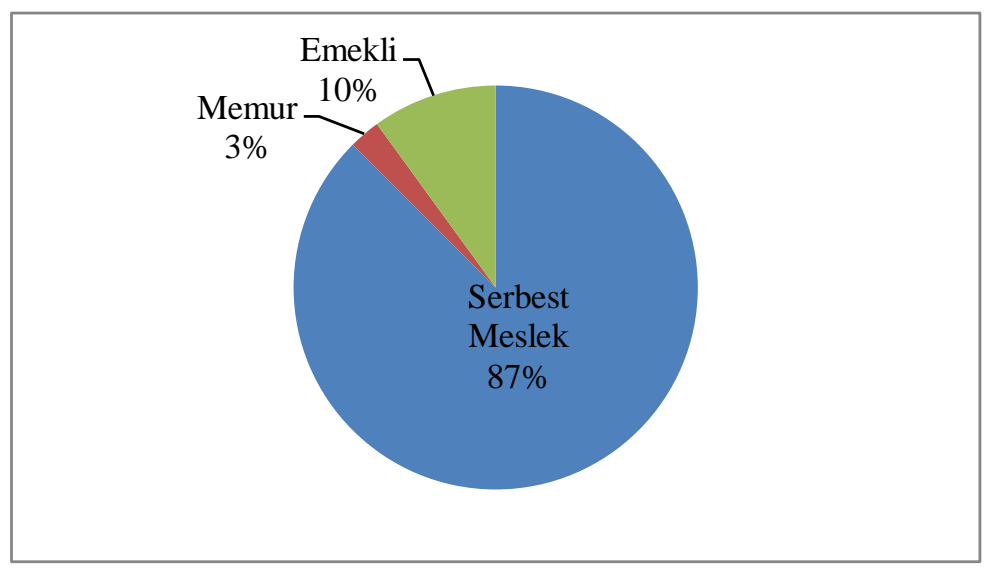

Şekil 5. Katılımcıların baba meslekleri.

Katılımcıların mesleki eğitim faaliyetlerine katılım düzeylerine ilişkin bulgular, yılda bir kez (\% 47) ile hiç katılmıyorum (\% 27) arasında değiştiğini göstermektedir. Mesleki eğitim faaliyetlerine ayda birkaç kez katılım \% 8 iken, yılda birkaç kez \% 15 , ayda bir kez \% 3 dür (şekil 6).

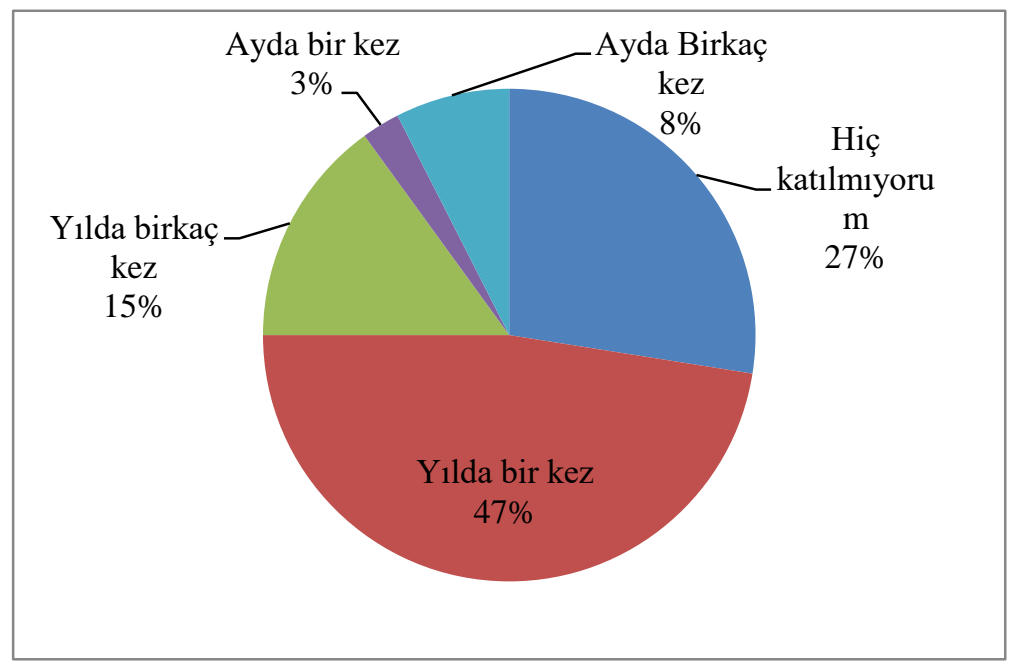

Şekil 6. Katılımcıların mesleki eğitim faaliyetlerine katılım düzeyleri.

Şekil 7' den görüldüğü gibi, yükleniciler genelde gazete ve dergi benzeri yayın organlarını okumaktadırlar. İnşaat sektörü ile ilgili yayın takip edenlerin oranı \% 25 tir. 


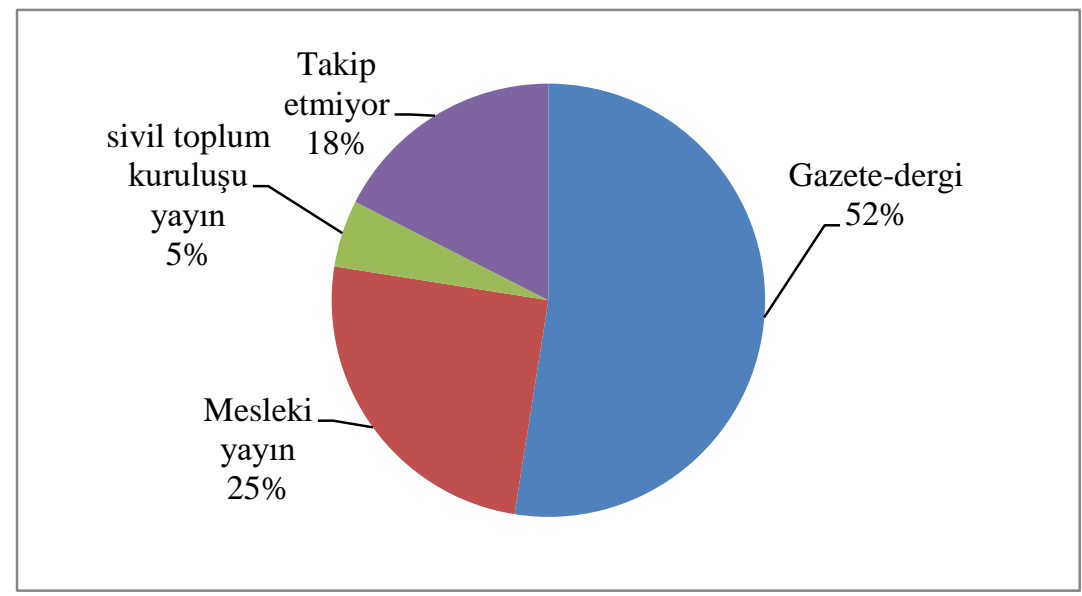

Şekil 7. Katılımcıların süreli yayın takibi.

Anketteki sorulardan cevabı evet (=1) / hayır (=2) olanlar Tablo 1'de özetlenmiştir. Tablo 1' e göre yer alan "Ailenizde kendi dışınızda yüklenicilik yapan var mıydı?" sorusuna 40 kişiden \% 62,5' i hayır cevabı vermiştir. Bu oran yüklenicilerin meslek seçiminde ailede bulunan yüklenicilerden hangi oranda etkilendiği sorusunu gündeme getirebilir. Örneklem grubu içerisinde yer alan yüklenicilerin \% 35'i Balıkesir dışında yüklenicilik faaliyeti yürütmektedir. Geriye kalan \%65 ise Balıkesir içerisinde iş yapmaktadır. Balıkesir dışında da yüklenicilik faaliyeti yürütmüş olanların, faaliyet yürüttükleri yerler büyük oranda Marmara Bölgesi'nde yoğunluk kazanmaktadır. Bulunan bu sonuç, Trabzon ili için yapılan çalışmada elde edilen mesleğin icra alanı olarak aidiyet kavramının etkili olduğu sonucuna benzerdir [5]. Ankete katılan yüklenicilerin \% 93' ü "kesinlikle yeteneklerine uygun" bir işte çalıştıklarını düşünmeleri, mesleği sahiplendikleri ve yaptıkları işten haz ve tatmin oldukları şeklinde yorumlanabilir. 40 yükleniciden $\% 72,5$ ' i mesleğinin herkesin yapabileceği bir meslek olmadığını, zira bilgi birikimi ve ustalık gerektiren özellikli bir meslek olduğunu belirtmişlerdir. Görüşülen yüklenicilerin $\% 7,5^{\prime}$ i, şehir veya şehirleşme ile ilgili herhangi bir kitap ismi bilmediklerini belirtmişler, sadece $\% 22,5$ ' i konuyla ilgili kitap ismi söylemişlerdir. Yüklenicilerin büyük bir bölümü şehirleşme konusundaki güncel verileri takip etmediklerini söylemişlerdir. Ne yazık ki, takip etme oranı $\% 17,5^{\prime}$ te kalmıştır. Tablo 1' de Ticaret odası dışında herhangi bir kuruluşa üye olanların oranı $\%$ 52,5 tir. $\mathrm{Bu}$ üyelik oranının artması örneğin STK üyelikleri sosyal-kültürel yapılarının daha güçlenmesine katkı sağlayacaktır. 'Balıkesirliler yüklenicilere güveniyor mu?', sorusuna verilen cevaplar \% 77, 5 oranında evettir. $\mathrm{Bu}$ oran yüklenicilerin kendine olan güvenlerinden ve kendi reklamlarını yapma açısından oldukça yüksek bir orandır. Yapılan bu anket çalışmasının araştırma aşamasında edinilen bilgilerde Türkiye'de önceden var olan müteahhitler (yükleniciler) birliği odasının tekrar kurulmasının faydalı olup olmayacağı sorulmuştur. \% 70 oranında böyle bir birliğin kurulması gerektiğini söylemiştir. Tablo 1' de görüldüğü gibi "Balıkesir' deki yüklenicilerin birbirleriyle olan ilişkileri yeterli midir?", sorusuna ankete katılanların verdiği cevaplara göre yarısından fazlası evet cevabı vermiştir. Görüşülen yüklenicilere "sizce yabancı dil yeterince bilinmeli mi? sorusunun cevab1 küçük ve orta ölçekli yüklenici firmaları olmaları sebebiyle Balıkesir dışında veya içinde büyük çaplı çok fazla iş yapmamalarından dolayı "hayır" cevabı veren katılımcıların bu oranı \% 50' dir. Ayrıca İSG (iş sağlı̆̆ alınmasının kurumsal baskının yanı sıra inşaat sektörü paydaşlarından olan yüklenicilerin sosyo-kültürel yapılarının bir parçası olması önemlidir. Bu nedenle 
yüklenicilerin sosyo-kültürel yapısını incelemeye yönelik bu çalışmada katılımcılara "yüklenicilerin yeteri kadar ISG önlemleri aldığını düşünüyor musunuz?" sorusu yöneltilmiş, bulgular \% 82 oranında İSG önlemlerinin alındığını göstermektedir.

\subsubsection{Katılımcıların Sosyo-kültürel yapıları ile demografik özellikleri arasındaki ilişki}

Katılımcıların sosyo-kültürel yapılarını ölçmeye yönelik sorular ile demografik yapıları arasındaki ilişki tablo 2' de verilmiştir. Çalışma kapsamında ikiden fazla grupların (yaş, eğitim, baba mesleği) bağımsız değişkenler arasındaki ilişkinin analizi için ANOVA analizi kullanılmıştır. Bulgular; yaş ile S6 (basılı veya online yayın takip ediyor) $(p \leq 0,05)$; S7 (kent ve kentleşme ile ilgili kitap/eser okuyor $(p \leq 0,05)$ değişkenleri arasında anlamlı bir ilişkinin olduğunu göstermektedir. Ayrıca eğitim ile S8 (kent, kentleşme ile ilgili süreli yayın takip ediyor) ( $\mathrm{p} \leq 0,05)$; $\mathrm{S} 9$ (ticaret odas1 dışında bir kuruluşa üyeliği bulunuyor) ( $p \leq 0,001)$, S11 (Balıkesir'de bir yükleniciler birliği olması gerektiğine düşünüyor) $(p \leq 0,05)$ ve $S 13$ (yüklenicilerin yeterince yabanc1 dil bilmesi gerekir) $(\mathrm{p} \leq 0,001)$ anlamlı ilişki bulunmaktadır. Baba mesleği ile S3 (kabiliyetine uygun bir işte çalışıyor) $(\mathrm{p} \leq 0,001)$ ve $\mathrm{S} 5$ (yükleniciliğin yeterli birikimi olan herkesin yapabileceği bir meslek olduğunu düşünüyor) $(\mathrm{p} \leq 0,001)$ arasındaki ilişki anlamlı ilişki bulguları arasındadır.

Tablo 1. Katılımcıların sosyo-kültürel yapılarını ölçmeye yönelik ifadeler

\begin{tabular}{|l|l|c|c|c|c|}
\hline \multicolumn{2}{|c|}{ SORULAR } & \multicolumn{2}{c|}{ Evet } & \multicolumn{2}{c|}{ Hayır } \\
\cline { 3 - 5 } & Sıklık & Yüzde & Sıklık & Yüzde \\
\hline S1 & $\begin{array}{l}\text { Ailede kendi dışınızda halen yüklenicilik } \\
\text { faaliyetinde bulunan var }\end{array}$ & 15 & $\% 37.5$ & 25 & $\% 62.5$ \\
\hline S2 & $\begin{array}{l}\text { Balıkesir dışında başka bir ilde yüklenicilik } \\
\text { faaliyetinde bulunuyor }\end{array}$ & 14 & $\% 35$ & 26 & $\% 65$ \\
\hline S3 & Kabiliyetine uygun bir işte çalışıyor & 38 & $\% 93$ & 2 & $\% 7$ \\
\hline S4 & Emeğinin karşıllğını aldığına inanıyor & 28 & $\% 70$ & 12 & $\% 30$ \\
\hline S5 & $\begin{array}{l}\text { Yükleniciliğin yeterli birikimi olan herkesin } \\
\text { yapabileceği bir meslek oluğunu düşünüyor }\end{array}$ & 11 & $\% 27.5$ & 29 & $\% 72.5$ \\
\hline S6 & Basılı veya online yayın takip ediyor & 31 & $\% 77.5$ & 9 & $\% 22.5$ \\
\hline S7 & $\begin{array}{l}\text { Kent ve kentleşme ile ilgili okuduğu bir kitap/eser } \\
\text { okuyor }\end{array}$ & 9 & $\% 22.5$ & 31 & $\% 77.5$ \\
\hline S8 & Kent, kentleşme ile ilgili süreli yayın takip ediyor & 7 & $\% 17.5$ & 33 & $\% 82.5$ \\
\hline S9 & $\begin{array}{l}\text { Ticaret odası dişında bir kuruluşa üyeliği } \\
\text { bulunuyor }\end{array}$ & 21 & $\% 52.5$ & 19 & $\% 47.5$ \\
\hline S10 & Balıkesir halk1 yüklenicilere güveniyor & 31 & $\% 77.5$ & 9 & $\% 22.5$ \\
\hline S11 & $\begin{array}{l}\text { Balıkesir'de bir yükleniciler birliği olması } \\
\text { gerektiğine düşünüyor }\end{array}$ & 28 & $\% 70$ & 12 & $\% 30$ \\
\hline S12 & $\begin{array}{l}\text { Aynı bölgede iş yapan yüklenicilerin birbirleriyle } \\
\text { olan ilişskileri yeterlidir }\end{array}$ & 21 & $\% 52.5$ & 19 & $\% 47.5$ \\
\hline S13 & Yüklenicilerin yeterince yabancı dil bilmesi gerekir & 20 & $\% 50$ & 20 & $\% 50$ \\
\hline S14 & Yükleniciler yeteri kadar İSG önlemi alıyorlar & 33 & $\% 82$ & 7 & $\% 18$ \\
\hline
\end{tabular}


Tablo 2. Katılımcıların sosyo-kültürel yapıları ile demografik özellikleri arasındaki ilişki.

\begin{tabular}{|c|c|c|c|}
\hline SORULAR & Yaș (Sig.) & Eğitim (Sig.) & $\begin{array}{l}\text { Baba } \\
\text { Mesleği (Sig.) }\end{array}$ \\
\hline S1 & 0,787 & 0,720 & 0,371 \\
\hline S2 & 0,482 & 0,864 & 0,643 \\
\hline S3 & 0,068 & 0,621 & 0,001 \\
\hline S4 & 0,664 & 0,622 & 0,826 \\
\hline S5 & 0,893 & 0,424 & 0,015 \\
\hline S6 & 0,013 & 0,489 & 0,867 \\
\hline S7 & 0,005 & 0,117 & 0,457 \\
\hline S8 & 0,096 & 0,042 & 0,566 \\
\hline S9 & 0,364 & 0,000 & 0,087 \\
\hline S10 & 0,106 & 0,742 & 0,056 \\
\hline S11 & 0,757 & 0,046 & 0,505 \\
\hline S12 & 0,205 & 0,601 & 0,647 \\
\hline S13 & 0,779 & 0,005 & 0,647 \\
\hline S14 & 0,328 & 0,205 & 0,194 \\
\hline
\end{tabular}

\section{Sonuçlar}

İnşaat sektörü yaşadığımız ekonomik dalgalanmaya karşın ayakta durabilmektedir. Türk İnşaat Firmaları ENR [9]' nin raporuna göre en iyi 250 firma arasına bu yıl 45 firma ile girmişlerdir. Ülkemizde bazı şehirlerin göç alması ile artan nüfusun barınmasına yönelik konut talebi, şehirde yaşayanların ihtiyaçları doğrultusunda yapılan yatırımlar; yol, köprü, tünel, eğlence merkezi vb. yüklenicilik mesleğini hızla yükselterek sektörün popüler paydaşı haline getirmiştir [1,8]. Ayrıca Balıkesir'de yerel yönetimlerin aldığı imar değişiklik kararları, kentsel dönüşümünün desteklenmesi ve getirdiği kazanımlar, Balıkesir'li olup ta başka illerde yaşayanların aidiyet duygusu ile emekli olunca dönerim düşünceleri doğrultusunda konut talebi, ilin coğrafi konumu, kıyı ilçelerinin varlığı, tarımsal anlamda üretkenlik sektörün paydaşları olan yüklenicilerin sayısını artırmıştır. 2018 yılı verilerine göre Balıkesir Ticaret Odası'na kayıtlı konut / inşaat alanında çalışan üye sayısı 572 dir. Bu üyelerden yaklaşık 60'1 yap-sat konut sektöründedir [11]. Aldığımız örneklemdeki 40 kişi tamamıyla bu şekilde faaliyet gösterenlerdir. Örneklemdeki kişiler ile yapılan anket ve mülakat, sosyokültürel yapılarını ortaya koyabilmek içindir. Katılımcıların sosyo-kültürel yapıları ile demografik özellikleri (yaş, eğitim, baba mesleği) arasındaki ilişki ANOVA analizi ile ortaya koyulmuştur. Yaş ile "basılı veya online yayın takip ediyor" ve " kent ve kentleşme ile ilgili okuduğu kitap/eser bulunuyor” değişkenleri arasındaki anlamlı ilişki; genç yüklenicilerin bu tür yayınları takip etme durumunun daha fazla olabileceği ve güncel gelişmelere ilgilerinin olduğu şeklinde yorumlanabilir. Eğitim ile, "kent ve kentleşme ile ilgili süreli yayın takip ediyor" ve "Ticaret Odası dışında bir kuruluşa üyeliği bulunuyor" değişkenleri arasındaki ilişki; eğitim seviyesinin yükselmesi mesleki süreli yayın takibinin ve oda ve benzeri kuruluşlara üyeliklerinin sosyo-kültürel seviyenin artması şeklinde düşünülebilir. Ayrıca; eğitim ile, "Balıkesir'de bir yükleniciler birliği olması gerektiğini düşünüyor" ve "yüklenicilerin yeterince yabancı dil bilmesi gerekir" değişkenleri arasındaki ilişki, grubun bir birlik çatısı altında daha güçlü ve kaliteli olabileceği düşünülebilir. Baba mesleği ile, "kabiliyetine uygun bir işte çalışıyor" ve "yükleniciliğin yeterli birikimi olan herkesin yapabileceği bir meslek olduğunu düşünüyor" değişkenleri arasındaki ilişki; baba mesleğini hazır iş olarak 
devam ettirmeleri, kurulu bir düzene dahil olmalarının avantajlarını kullanmak istemeleri yönünde bir seçim olabilir. Elde edilen sonuçlar 1şığında sosyo-kültürel yapılarındaki zenginliği ve almış oldukları teknik eğitimi mesleklerine aktararak icra edenler olduğu gibi, hiçbir eğitim almadan sadece maddi birikimleri ile faaliyet gösteren kişilerde mevcuttur. Ancak; yükleniciliği herkes yapabilir mi? sorusunun cevabının $\%$ 72,.5 hayır olması sevindiricidir. Anket değerlendirmesinde; yüklenicilerin çoğunun Balıkesir doğumlu olduğunu görüyoruz. Bu yüklenicilerin orta ölçekli işler yapmaları, yabancı firmalar ile çalışmamaları neticesinde dil konusunda herhangi bir ilgilerinin olmadığı ortaya çıkmıştır. Balıkesir ili genelinde faaliyette olan yükleniciler sosyo kültürel yapıları doğrultusunda elde ettikleri kazanımları olumlu ve olumsuz şekilde sektöre yansıtmaktadırlar. Çalışma bu anlamda elde edilen sonuçların ortaya koyulması açısından değerlidir. İl merkezi ile sınırlı bu çalışmanın Ülke genelinde farklı değişkenler için geliştirilmesi yapılabilir. Bununla birlikte Türkiye Müteahhitler (Yükleniciler) Birliği kapsamında, sosyo-kültürel yapıları, düzenlenecek mesleki eğitimler ile güçlendirilerek mesleğini seven, değer veren, saygı duyan, okuyan, mesleki gelişmeleri takip eden ve daha optimist bireylerin sektörde söz sahibi olması bir kazanım olabilir. Ne yazık ki; inşaat sektöründe görev yapan yükleniciler ile ilgili herhangi bir mesleki yeterlilik kriteri olmayışı sosyo-kültürel açıdan da bir olumsuzluktur. Mesleki yeterlilik adı altında yapılacak yasal düzenlemeler teknik eğitim ve sosyo-kültürel alanda yüklenicilik mesleği pratiklerini icra edenlere değer katacaktır.

\section{Kaynaklar}

[1] Birgönül, M.T., Dikmen, I., Özorhon B., Işık Z., İnşaat sektörünün yapım yönetim eğitiminden beklentileri Üçüncü Yapı İşletmesi Kongresi, Bildiriler Kitabı, İnşaat Mühendisleri Odası, İzmir, 29-30 Eylül 2005, 169-178, (2005).

[2] Kuruoğlu, M., Arslan, M., Türk İnşaat Sektöründe Proje Yöneticileri için Bilgi ve Becerilerin Değerlendirilmesi, IV. Mimarlık Mühendislik Sempozyumu, Haziran 2002, Balıkesir, (2002).

[3] Jahoda, G., Crossroads between culture and mind: Continuities and change in theories of human nature, New York, Harvester Wheatsheaf. (1992)

[4] Akıner, İ., Esin, N., Giritli, H., Türk inşaat endüstrisinde iş değerleriyle ilgili kültürel profil, İTÜ Dergisi Seri A: Mimarlık, Planlama, Tasarım, 4(2), 4758, (2005).

[5] Karyelioğlu S., Türkiye'de İnşaat Sektörünün Gelişimi Bağlamında Trabzon'da Müteahhitliğin Sosyokültürel Temelleri, Karadeniz İncelemeleri Dergisi, 19, 207-240, (2015).

[6] Tekeli, İ., İlkin, S., Uluslararası İnşaat sözleşmesi modeli olarak FIDIC inşaat işleri sözleşme şartları,Abant İzzet Baysal Üniversitesi Sosyal Bilimler Enstitüsü Dergisi, 20, 1-2, (1993).

[7] KMPG, Sektörel Bakış-İnşaat, (2018).

[8] İNTES,İnşaat sektörü raporu, Mayıs 2018, (2018).

[9] ENR, Engineering News Records . https://www.enr.com/toplists/2018-Top250-International-Contractors-1, erişim tarihi: 05.10.2018

[10] https://www.mynet.com/balikesir/hakkinda : erişim tarihi: 06.10.2018

[11] Balıkesir Ticaret Odası web sayfası: https://www.bato.org.tr: erişim tarihi: 06.10 .2018 